\title{
THE SOCIAL POSITION OF WOMEN IN CITIES IN THE USA DURING THE 1960S-1980S
}

\author{
Vlada V. Koroleva (a) \\ (a) Department of Cultural Studies, Philosophy of Culture \& Aesthetics, Institute of Philosophy, St \\ Petersburg State University. Mendeleevskaya 5, St. Petersburg, Russia 199034. \\ E-mail: koroleva1994[at]me.com
}

\begin{abstract}
The article is dedicated to the problem of the position of women in cities and to creation and formation of "women's spaces" in the United States in 1960-1980.

Following the development of the second wave of feminism, we focused the attention not only on the movement for civil rights itself but also on the activities of organizations and women who were trying to improve the living conditions of female citizens.

Prisoners in their homes, women have always been associated more with the suburbs than with the cities themselves. They were never seen as citizens, but rather as rare guests in this urban space.

In order to make cities more women-friendly, feminists began to create exclusive women's spaces that would help women not only get out from their house-arrest but also solve difficult life situations. Shelters, women's health centers, women's libraries, book clubs and kindergartens - all of these new spaces helped an American woman move out of the alienation spaces of their houses and gain new opportunities for selfdevelopment.
\end{abstract}

\section{Keywords}

Feminism; women's spaces; city; suburbs; USA; shelter; racism; sexism; women rights; civil rights

This work is licensed under a Creative Commons «Attribution» 4.0 International License. 


\title{
СОЦИАЛЬНОЕ ПОЛОЖЕНИЕ ЖЕНЩИН В ГОРОДАХ США В 1960-Е - 1980-Е ГГ.
}

\author{
Королева Влада Владимировна (а)
}

(а) СПбГУ, Кафедра культурологии, философии культуры, и эстетики. 199034, Россия, СанктПетербург, Менделеевская линия д. 5. E-mail: koroleva1994[at]me.com

\section{Аннотация}

Статья посвящена проблеме положения женщин в городах, а также созданию и формированию «женских пространств» в Соединенных Штатах Америки в 19601980-х годах.

Следуя за развитием второй волны феминизма, мы сосредоточили внимание не только на самом движении за гражданские права, но и на деятельности организаций и женщин, которые пытались улучшить условия жизни горожанок.

Заключенные в своих домах, женщины всегда больше ассоциировались с пригородами, чем с самими городами. Их никогда не воспринимали как горожан, а скорее как редких гостей в этом городском пространстве.

Чтобы сделать города более удобными для женщин, феминистки начали создавать эксклюзивные женские пространства, которые помогали бы не только выйти изпод домашнего заключения, но и решать трудные жизненные ситуации. Приюты, женские оздоровительные центры, женские библиотеки, книжные клубы и детские сады - все эти новые пространства помогли американской женщине выбраться из отчужденных пространств своих домов и получить новые возможности для саморазвития.

\section{Ключевые слова}

Феминизм; женские пространства; город; пригород; США; приют; расизм; сексизм; права женщин; гражданские права.

Это произведение доступно по лицензии Creative Commons «Attribution» («Атрибуция») 4.0 Всемирная. 


\section{INTRODUCTION}

If we consider the situation in general that took place in the second half of the 20th century, of course we could see some improvement in the social position of women in cities. However, at the same time, the situation was completely different even within the same city for women of different social classes, ethnicity, sexual orientation, marriage status.

In our research, women's places in the cities were studied, as well as women's position in a family and workplace, civil and legal rights, violence against women in cities and services that were mainly used by women. We have tried not only to study the position of white middle-class women, but also to find out the differences in the position of minorities and lower-class women compared to the majority of female citizens. The period of the 60s-80s was chosen because of the revolutions, movements for the civil rights and significant changes that happened in USA during that time.

The position of women in cities changed a lot after the II World War. On one hand, it was the era of women's rights' significant improvements but on the other hand, first years after the war were years of "redomestication" of women. Women took over jobs in the cities while their husbands were fighting at the battlefield, but later they were forced to give it up and return to their kitchens after men came back (Weissbrodt, 1946). That caused many complaints from women as the labor force and opened up a discussion about equality and women's position in cities and society.

The Second wave of feminism in its fight for women's rights created possibilities for women to use urban space daily. The cities started opening up and became more "women-friendly". During this period new kind of gendered spaces opened by and for women appeared in cities and suburbs across the USA. The big difference between women's spaces and segregation places is as follows: women places were voluntary. Gendered spaces that existed in cities before were based on segregation of men from women in such urban spaces as school, workplaces, houses, colleges (or some faculties). They were created not to help women, but to reduce their access to knowledge, power, civil services and lower their status in cities. That segregation, unlike women's spaces, was mandatory for female citizens (Spain, 2016).

\section{WOMEN'S MOVEMENTS}

All changes in the gender landscape of the city became possible only due to the long history of women's movements. One of the first women's centres, the Women's Educational and Industrial union, was 
opened a hundred years before the Second Wave in 1877 on Boylston Street in order to provide a possibility for economic and intellectual independence for elite and middle-class women. They were active members of the community and influenced positive improvements in water and air quality, public health and children welfare. They were a sort of "municipal housekeepers" because they took care of the local commune the same way they took care of their houses.

Women also establish such new spaces as "neighborhoods living rooms" in order to help immigrants to adapt in a new society and safe community from the suffering of newcomers (Spain, 2011). However, what is important here is that starting from the 1960s their focus changed from the needs of society to the needs of female citizens.

After the loss of population in the 1950s because of intensive suburbanization, the government launched an urban renewal in order to save cities from depopulations. They destroyed slums and built public houses that cause huge migration, mostly of African American families. The high-rise public houses and the blight caused by renovation did not attract people to move back to the cities but pushed them to suburbs. In the 1950s and 1960s, the dichotomy between cities and suburbs increased, and urban spaces became identified by the gender of the majority of inhabitants (Spain, 2011). The daytime cities population was identified as masculine because the majority of jobs were occupied by men and a vast number of everyday migration of men from suburbs to cities in order to work. $90 \%$ of men population was at the labour force which means that they spent most of their lifetime in the cities. ${ }^{1}$ Suburbs were identified with femininity, housekeeping, and passiveness. Around $70 \%$ of women did not work and spent most of the time at their houses.

The women's movement changed this situation a lot. After Betty Friedan published her "Feminine Mystique" in 1963 and the book became a bestseller, feminism and feminist's discourse started gaining popularity. In 1966 Friedan along with other feminists founded the National Organization for Women (NOW). This organization became an essential part of the women's movement. NOW held a convention in 1967 and issued the Bill of Rights with the demands of equal rights and opportunities for women. At the same time, this organization was often considered as anti-male, and many feminists of the movement were not members of NOW and preferred organizations that were not so radical. (Evans, 1995)

We also could say women's conventions, protests, demonstrations and marshes themselves made women more visible in cities. They were not just

\footnotetext{
1 That's why even if their houses were at the suburbs, many sociologists consider them as "cities inhabitants".
} 
silent observers but took an active part in the life of cities. They tried to influence political decisions by protesting and issued leaflets and newspapers with their demands.

Moreover, here it is necessary to mention that they were not only fighting for women's rights but also took an active part in other movements in the cities such as protests against Vietnam war, discrimination of black and gay people. However, at the same time, there were many problems within the movement and discrimination against lesbians and black women. That caused the foundation of new organizations, such as the National Black Feminist Organization (NBFO). (Nicholson, 1996).

\section{RACISM}

Here we should mention that in America the social position of women in cities was strongly depended on their race, sexual orientation and social stratum. Those who did not fit to the image of white middle-class heterosexual woman had a lower position in the society and a range of problems that white female citizens never faced. De facto racial segregation was still strong despite de jure changes in the 60s when Civil Rights Act (1964), the Voting Rights Act (1965), and the Fair Housing Act (1968) were voted.

Women of colour had suffered from the problem of double discrimination: as women and as people of colour. The segregation of public facilities on coloured and white was a grave issue in the 20th century. People of colour were not allowed to join facilities and spaces that were reserved for white people. They had to eat, drink and live in coloured neighbourhoods that were overpopulated, to sit at the back rows in public transport or use buses for people of colour (McWhorter, 2009). For example, civil right activist Rosa Parks was arrested in 1955 because she did not give up her seat to a white passenger. Her arrest caused a huge Montgomery bus boycott (Williams \& Greenhaw, 2005).

Women of colour mostly lived in overpopulated and unsafe neighbourhoods and were in danger of rape, robbery, and murder. They were easy targets for the criminals and especially for members of the third $\mathrm{Ku}$ Klux Klan (KKK) that became popular again as resistance to the civil rights movement. Women of colour did not have support and protection from the legal system, and often people who committed crimes against them (mostly white men) were acquitted by an all-white jury or given short prison sentences. It is also necessary to mention that some of the police officers and men who worked in a legal system were themselves members of KKK (Dobratz, 2000). 
NBFO that was established in 1973 by Florence Kennedy and Margaret Sloan protests against all these forms of discrimination including those members of the Feminist movement who were racists going against women of colour. They were focusing their efforts on the reproductive and mental health of black women, campaigning against sterilization abuse and for the right for safe abortions. They founded the National Black Women's Health Project (NBWHP) in 1983 (Spain, 2016).

\section{FORCED STERILIZATION}

The ecological situation and poverty at colour neighbourhoods and fast spread of diseases such as tuberculosis put the health of inhabitants in danger. Women who lived there had less access to public health facilities and education. Another big problem that they faced was forced sterilization. Eugenic sterilization happened in the USA from the beginning of the 20th century and was almost stopped before the war. However, after the II World War, Dr. Clarence Gamble started practicing the sterilization again. Black, Latina, Hispanic, and Native American women were the primary targets of this process (Jarrell, 1992). Doctors used different ways to force women to consent to the procedure. Gamble himself told women and their daughters that they need shots but instead of that sterilized them. There was a bunch of cases when this procedure was made without consent or knowledge of the victim. Native American, Hispanic and Latina women, sometimes unknowingly, gave consent because they did not know the language (Torpy, 2000).

However, most women were threatened that they would lose welfare benefits for their children and families if they did not agree to the sterilization (Lawrence, 2000). That makes the position of women of colours in cities even more vulnerable and unprotected than the position of white women.

\section{WOMEN'S SPACES.}

By taking over jobs in cities women made them less masculine, and at the same time pushed some jobs to suburbs. Women for the first time started visiting places in the cities that were considered as completely masculine before, for example, elective offices, board rooms. The private man clubs were slowly disappearing or turning into nongendered clubs, and bars stopped to be exclusively men's leisure places where they were resting after the working day; now they serve both genders. After gaining access to spaces that were occupied exclusively by men before, women went forward and started to create "women's spaces" in the cities. Most of them were influenced by particular problems that were in focus of the feminist 
movement. Women's Health clinics were opened in order to fight against birth control and provide women with information about contraception and reproductive health. The solution to the problems of domestic violence and needs of personal safety became shelters for victims of domestic abuse. The willing to show and express their identity created women's centres, banking facilities, and feminist bookstores (Spain, 2016).

The appearance of such female spaces made women visible in the cities. They are no longer just housekeepers and invisible maintainers of neighbourhoods. At the same time, the situation with shelters for the victims of domestic violence was a bit different. The locations of these places had to remain in secret in order to protect women from their husbands and families. However, the existence of these shelters itself gave women a possibility to run away from the poisoning environment and start a new life that they did not have before. That new life helped those who were trapped in their houses for years to open up cities for themselves, gain jobs and chances to make their own decisions (Spain, 2011).

\section{WOMEN'S CENTRES}

The primary goals of all women's centres were to serve all women and provide all necessary information, spread maps and lists of addresses of women facilities in the city, give access to and sell women's books, magazines, newspapers, organize meetings with feminist activists and authors. Centres were essential meeting places both for feminist activists and women. They discuss the problems of modern women movements, the ways one can improve the position of women in the cities and society. Centres also organize campaigns against rape and violence and provide psychological help for victims. They also organized Rape Crisis Centres which not only helped to solve the phycological problems but also provided legal help for those who have decided to report the crime, even if $90 \%$ of incidents were never reported. Another goal of the crisis centres was to change the public attitudes towards victims. They visited high schools and universities, appeared on radio, wrote articles to newspapers and organized such events as Anti-Rape Squad. Women activists opened Self-Defence courses, too. Women's centres became also alternative places for gathering outside bars for women who experienced problems with drugs and alcohol (Spain, 2016).

\section{HEALTH CLINICS}

In 1977 NOW issued a "Selected Guide to Women's Resources" that provide a list of numerous women's spaces and services, mainly in Boston that was a centre of feminist movement of that time (Spain, 2016). 
Radical groups such as "Women's International Terrorist Conspiracy from Hell" (WITCH), "The Furies", the "Society for Cutting Up Men" (SCUM), "Bread and Roses" (from Boston) were the most noticeable within the movement. They not only organized parades and published books that made the female discourse more visible in the cities but also established important women's services. Radical feminist founded the Women's Community Health Centre in 1973 in Boston in order to give female citizens access to high-quality, safe and low-cost medical services. Later similar centres were open in many cities in the USA. These centres pose that access to excellent health services is one of the primary human rights and should be free of charge. Services had no fees, but founders of the centre believed that wealthy women would voluntarily pay in order to finance the services for those who cannot pay. Because of this economy politics the centre was closed due to bankruptcy in 1981 (Spain, 2016).

\section{SHELTERS}

At the beginning of the 1960s cities were not a safe place for women in terms of domestic violence, but there were safer than suburbs. Many women including Betty Friedan admitted that domestic violence started after their families moved to suburbs. However, domestic violence was still a "normal reality" even in the cities. The domestic violence was a tabooed topic; it was not openly discussed in public spaces in cities. There was no legal protection to women who were victims of abuse: restraining orders and shelters still did not exist, and women had to come back home to the abuser or try to hide at their friends' houses. The first shelters were established in the early 1970s by members of women's movement. Women activists around the country started forming organizations that were making cities safer and friendlier for women. For example, in Boston there were established Somerville Women's Health Project (WMP), the Women's Mental Health Collective (WMHC) and the Somerville Community Corporation (SCC). The primary goal of SCC was to buy and renovate houses for rent and sale for mainly low-income women and families. Members of the community also helped women to get off welfare, buy houses, provide shelters for runaway women teenagers and victims of domestic abuse (Spain, 2011). This organization was not radical and tried to seek help from everyone willing to help.

Moreover, this had positive results; for example, a man- major Lester Ralf donated the first shelter. In a short amount of time the organization opened a few other shelters around the city, but there were much more women seeking a safe place from their husbands and families than available places. For this reason, members of women's organizations that 
were arranging shelters, for example, RESPOND ${ }^{1}$ Inc., often invite victims to their apartments or summer houses if the shelter had no spare beds. Some shelters were open exclusively for women and did not welcome men on any ground; others were welcoming mothers with their adolescent sons.

At the same time the cities were not welcoming even the existing of shelters. Boards of assessors were often against the non-profit houses at the residential neighbourhoods; neighbours themselves, too, complained about shelters at their streets and buildings. In Boston RESPOND succeed in protecting shelters in Oak Street despite all complaints from the commune. Organizations always took the security of the shelters seriously. Women who worked there were not allowed to give up the location of safe houses or arrange meetings nearby. Women whose locations were declassified were moved to another safe house using the network of a coalition of shelters in the city. In extreme cases, women were moved to another state with the help of other women groups or organizations (Spain, 2011).

Later the organization opened an office and started paying for their stuff, for many women worked there as volunteers earlier. It also could be an example of a usual position of women in the cities, when they were no longer staying at home but did volunteering work.

\section{GALLERIES FOR WOMEN ARTIST}

One of the first galleries that would exhibit exclusively female artists was established in resistance to those museums and spaces that were declining to present women's art. The galleries also served as open women's places for celebrations, presentations of books and public talks of the famous feminist authors; there were offices, restaurants, and bookshops. One of the most famous specimen is Woman's Building in Los Angeles (Spain, 2016).

\section{WOMEN'S BANK OFFICES}

Until the "Equal Credit Opportunity Act" was voted for in 1974, many banks refused to issue a credit card for a woman, if she was unmarried, or even if she was married without her husband signature confirmation. Even after it became illegal to refuse to issue credit cards to female customers based on their gender, banks tried to find other reasons to decline their applications. That created a necessity to establish bank offices in the city that would serve only female clients (McLaughlin, 2014).

\footnotetext{
${ }^{1}$ Founded in 1975 by Jean Luce. The acronym RESPOND means Responsible Escape for Somerville People through Options and New Development.
} 


\section{COFFEE HOUSES \& BARS}

Woman's Coffee Houses and bars appeared in the cities in the 70s and served as hubs for mainly white middle-class lesbians and feminists. Coffee Houses were mainly used as meeting or working places that helped to operate the movement, organize events, books presentations, or used as a safe place where women could spend time outside of home or work. Coffee houses were also meeting points for feminist activists from different cities. Bars mainly used as leisure places and for lesbians especially were an alternative of "normal" bars where they were not available to show any signs of lesbianism (Enke, 2007).

\section{BOOKSTORES AND WOMEN'S LIBRARIES}

Feminist bookstores and libraries were places for presenting feminist literature, movements' materials and places for gathering. They were selling (or loaning) books, music, jewellery, and art that were written and created only by women. That was very helpful for female artists who were underrepresented and not taken into consideration by "normal" bookstores and libraries. "Sisterhood bookstores" tried to be comfortable and safe places for women in the cities; usually they had feminist posters on the walls, organized coffee shops and workplaces, and of course provided help and information for women in difficult situations. They organized public talks to give the guests information about the movement and women's rights. They also tried to provide legal help for women (Spain, 2016).

\section{JURY SERVICE}

In many cities ${ }^{1}$, women were not allowed to serve in a jury until 1973. That means that the decisions on cases that considered crimes against women were judged by men and could be biased because of the patriarchal bend in the society. There were cases where all-white-men jury acquitted men on violence charges without any reasons to do so. Without equal representation in the jury, women could not be sure that cases against them or cases where they were victims would be judged fairly (Mclaughlin, 2014).

\section{KINDER CARE HOUSES AND ADULT DAY SERVICES}

Kinder Care houses could be considered as women's spaces in the cities for two reasons: women made the majority of workers there, and they were made for women who were at the labour force and could not stay

\footnotetext{
${ }^{1}$ The situation with the rights to serve in a jury was different from state to state.
} 
home with their children. KinderCare opened the first Kinder Care Nursing School in 1969. The growth in the number of working mothers from 1955 to in 1980 made those kinder gardens a very successful project and very important for the convenience of women in the cities. By the time when the company went public in 1972, they already had 20 centres and this number rose to 300 by the company's tenth anniversary. Even if, at the very beginning, only 8 percent of children with working mothers attended kinder care houses, the existence of them was essential for improving the position of women in cities. By 1985 the KinderCare alone together with three other companies were operating 1747 kinder gardens (Spain, 2016).

Besides taking care of children, women were responsible for the wellbeing of elderly family members. In order to take care of old members of the family women often had to miss their job or cut working hours; that cost them money and sometimes workplaces. The fact that more and more women were involved in labour created the necessity to open facilities to take care of old adults. Adult day services (ADS) were an alternative for home care and gave women possibilities to proceed with their careers. ADS, as well as kinder gardens, also gave workplaces for women. In 1980s most of the workers in kinder gardens and ADS were women. ADS improve the quality of women's lives and reduce the level of stress. They no longer have to choose between their family and work (Spain, 2016).

\section{HIGH EDUCATION}

Starting from the 1970s women finally had got a chance to attend the Ivy league universities and not only women colleges, but it also happened because those universities were merged with women colleges. Brown started accepting women in 1971, Dartmouth in 1972, Harvard in 1977 and Columbia in 1982. So, before that, the number of places that provided the best quality high education for women in the cities was minimal. (Mclaughlin, 2014).

Universities preferred to accept mostly male students, especially in such fields as economy, medicine, law, and politics. Women were still mostly attending women's colleges even if these colleges were included in the system of non-gender universities. The reason why we cannot call women's colleges "women's spaces" is that those colleges were based on segregation in education between men and women. In women's colleges, they could study only subjects that were considerate as "feminine" and the level of education in those places was not as good as at non-gendered universities. 


\section{WORK}

The position of women at work was lower than the position of men. Even after The Equal Pay Act was voted in 1963, women did not make the same as men did. It can be explained by many reasons. First of all, they occupied mostly low positions at the workplaces. Neither did they have a chance to become managers of companies and directors. Because of the worse level of education women mostly could not occupy high skilled jobs. As already was mention women had to do housework, take care of children and old members of the family, cook. In order to do this, they had to cut their working hours and earned less. However, women's spaces, centres, and facilities created new working places for women, and feminism made it possible (but of course in sporadic cases) for women to participate in politics, become government officials, and occupy higher positions than before (Spain, 1992).

\section{CONCLUSION}

The position of women in the USA cities during 1960s-1980s was not equal to men's. The biggest problem was the level of violence and especially domestic violence that forced female citizens to establish new safe places in the cities, such as shelters and women's centres. Women also suffered from the similar problems in the sphere of education and work. They were either forced to work or pushed from work to their houses without considering their opinions. Another serious problem was forced sterilization and birth control. At the same time women began to be active members of the feminist movement and gained more benefits and positive changes in their life.

I think that the position of women in the cities rose during the postwar period. However, there were still many differences between the position of women in the protected women spaces and in public sphere. Women did not gain the right to be equal to the men citizens yet, but they became closer to do it.

\section{References}

Dobratz, B. A. \& Shanks-Meile, S. L. (2000). The White Separatist Movement in the United States: "White Power, White Pride!". Baltimore, MD: JHU Press

Enke, A. (2007). Finding the Movement: Sexuality, Contested Space, and Feminist Activism. Durham: Duke University Press

Evans, J. (1995). Feminist theory today: An introduction to second-wave feminism. London; Thousand Oaks, Calif.: Sage Publications. 
Jarrell, R. H. (1992). Native American women and forced sterilization, 1973-1976. Caduceus: a museum quarterly for the health sciences, $8(3)$, p. 45-58.

Lawrence, J. (2000). The Indian Health Service and the sterilization of Native American women. American Indian quarterly, 24(3), pp. 400419.

Mclaughlin, K. (2014). 5 things women couldn't do in the 1960s. CNN.com CNN. Retrieved from: http://edition.cnn.com/2014/08/07/living/sixties-women-5-things/

McWhorter, L. (2009). Racism and sexual oppression in Anglo-America: A genealogy. Bloomington: Indiana University Press.

Nicholson, L. (1996). The second wave: A reader in feminist theory. New York: Routledge.

Spain, D. (1992). Gendered spaces. Chapel Hill: University of North Carolina Press.

Spain, D. (2011). Women's Rights and Gendered Spaces in 1970s Boston. Frontiers: A Journal of Women Studies, 32(1), pp. 152-178.

Spain, D. (2016). Constructive feminism: Women's spaces and women's rights in the American city. Ithaca: Cornell University Press.

Torpy, S. (2000). Native American Women and Coerced Sterilization: On the Trail of Tears in the 1970s. American Indian Culture and Research Journal, 24(2), pp. 1-22.

Weissbrodt, S. R. (1946). Women Workers in Ten War Production Areas and Their Postwar Employment Plans. Washington, D.C.: U.S. Government Printing Office. (U.S. Women's Bureau. Bulletin, 209).

Williams, D. \& Greenhaw, W. (2005). The Thunder of Angels: The Montgomery Bus Boycott and the People who Broke the Back of Jim Crow. Chicago Review Press.

\section{Список литературы}

Dobratz, B. A. \& Shanks-Meile, S. L. (2000). The White Separatist Movement in the United States: "White Power, White Pride!". Baltimore, MD: JHU Press

Enke, A. (2007). Finding the Movement: Sexuality, Contested Space, and Feminist Activism. Durham: Duke University Press

Evans, J. (1995). Feminist theory today: An introduction to second-wave feminism. London; Thousand Oaks, Calif.: Sage Publications.

Jarrell, R. H. (1992). Native American women and forced sterilization, 1973-1976. Caduceus: a museum quarterly for the health sciences, 8(3), p. 45-58. 
Lawrence, J. (2000). The Indian Health Service and the sterilization of Native American women. American Indian quarterly, 24(3), pp. 400419.

Mclaughlin, K. (2014). 5 things women couldn't do in the 1960s. CNN.com CNN. Retrieved from: http://edition.cnn.com/2014/08/07/living/sixties-women-5-things/

McWhorter, L. (2009). Racism and sexual oppression in Anglo-America: A genealogy. Bloomington: Indiana University Press.

Nicholson, L. (1996). The second wave: A reader in feminist theory. New York: Routledge.

Spain, D. (1992). Gendered spaces. Chapel Hill: University of North Carolina Press.

Spain, D. (2011). Women's Rights and Gendered Spaces in 1970s Boston. Frontiers: A Journal of Women Studies, 32(1), pp. 152-178.

Spain, D. (2016). Constructive feminism: Women's spaces and women's rights in the American city. Ithaca: Cornell University Press.

Torpy, S. (2000). Native American Women and Coerced Sterilization: On the Trail of Tears in the 1970s. American Indian Culture and Research Journal, 24(2), pp. 1-22.

Weissbrodt, S. R. (1946). Women Workers in Ten War Production Areas and Their Postwar Employment Plans. Washington, D.C.: U.S. Government Printing Office. (U.S. Women's Bureau. Bulletin, 209).

Williams, D. \& Greenhaw, W. (2005). The Thunder of Angels: The Montgomery Bus Boycott and the People who Broke the Back of Jim Crow. Chicago Review Press. 